\title{
BIOLOGICAL EFFICACY OF MYCOFLORA ISOLATED FROM MUSHROOM SUBSTRATE AGAINST PATHOGENIC FUNGI
}

\author{
M.A.R. Sarker, N. Sultana and K. Akhter* \\ Department of Plant Pathology, Sher-e Bangla Agricultural University, Dhaka
}

\begin{abstract}
Four fungi isolates, Aspergillus flavus, Aspergillus niger, Trichoderma harzianum, Penicillium sp. were isolated from mushroom substrates and identified. Biological activities these fungi were evaluated against three plant pathogens namely against Fusarium oxysporum, Sclerotium rolfsii, Colletotrichum corchori. Among the fungal isolates, Trichoderma harzianum showed the highest antagonistic activity against all three pathogens, Penicillium sp. showed less significant antagonistic activity than Aspergillus niger and Aspergillus flavus. Trichoderma harzianum showed the highest inhibitory effect in case of Fusarium oxysporum $(71.75 \%)$ followed by Sclerotium rolfsii $(61.64 \%)$ and Colletotrichum corchori (57\%).
\end{abstract}

Keywords: Antagonistic effect, Biological efficacy, Pathogenic fungi, Mycelial growth inhibition

\section{INTRODUCTION}

Mushrooms, belonging to class Basidiomycotina, are non-green fungal plants occurring seasonally all over the world. Among the 2000 edible species from 10,000 of different types of mushrooms, Oyster mushroom (Pleurotus ostreatus) is suitable for the climatic condition of Bangladesh and on the basis of consumption the oyster mushroom is on the second position after button mushroom word widely (Sanchez, 2010). In mushroom cultivation, substrates play the same role as soil executes in plant production (Kwon and Kim, 2004). Sawdust, cotton seed straw, cereal straw, corncob, sugar cane straw, newspaper, waste paper and other plant fibres prevailed in agro and wood industry showed promising result in case of cellulose content (Ragunathan et al., 1996; Kwon and Kim 2004).

The substrates harbour many weed fungi which act as competitor moulds either by competition for food material or through production of toxic substances (Vijay and Sohi, 1987). Isolated Aspergillus fumigatus, Chetomium thermophile, Mucor pusillus

\footnotetext{
* Corresponding Author: khadijaakhter@ymail.com
} 
and T. harzianum from straw and oyster compost substrates (Wickremasinghe et al., 1999). Different saprophytic and plant pathogenic fungi occurring in the substrate and competing with mushroom mycelium for space and nutrition are Aspergillus niger, A.flavus, Alternaria alternata, Drechslera bicolor, Fusarium moniliforme, Mucor sp., Penicillium sp., Rhizopus sp., Rhizpus stolonifer, Sclerotium rolfsii,, Trichoderma viride (Sharma et al., 2007; Sharma and Kumar, 2011). Some of these fungi can be used for biological control of different pathogenic fungi like Sclerotium rolfsii, Colletotrichum sp. and Fusarium spp.

The present study was undertaken to isolate, identify and characterize the fungi associated with selected mushroom substrate and to evaluate their efficacy against three selective pathogenic fungi.

\section{MATERIALS AND METHODS}

The experiment was conducted at the Molecular Plant Pathology Laboratory of the Department of Plant Pathology, Sher-e-Bangla Agricultural University, Dhaka, and Biochemistry laboratory and Mushroom Culture House $(\mathrm{MCH})$ of Biochemistry, Department, Sher-e-Bangla Agricultural University, Dhaka, Bangladesh. This study was conducted during the period of January, 2017 to June, 2017.

\section{Isolation of fungi on PDA media}

Isolation was done from three kinds of substrates samples (rice straw, saw dust, waste paper). Three contaminated polybags of rice straw was randomly selected from the inoculated polybags. The stock solution was made by taking $1 \mathrm{gm}$ of substrate from each polybag and mixing them with $100 \mathrm{ml}$ sterile distilled water in a conical flask. Then dilution plate technique was followed as described by Dhingra and Sinclair (1985). The same process was also followed in case of saw dust and newspaper poly bags. After finishing the preparation of different dilution, $0.1 \mathrm{ml}$ of $10^{-2}$ and $10^{-3}$ dilution was spread over PDA plate previously dried (to remove excess surface moisture) at three replications as described by Goszczynska and Serfontein (1998). The solution was spread with the help of sterilized glass-rod. The inoculated PDA plates were kept in incubation chamber at $25 \pm 1{ }^{\circ} \mathrm{C}$. The colonies grown over on PDA were recorded after 3-5 days of incubation. Sub cultures were made by transferring a bit of mycelia from the spread plate and transferred on PDA plates using the hyphal tip culture techniques (Tuite, 1969; Mian, 1995) to a new petri dish on the basis of color and morphology of the colony. Identification was done with the help of different books, manuals and publications following the keys suggested by Barnet (1980), Barnett and Hunter (1992), Watanabe (2000), Mathur and Kongsdal (2003), Malone and Musket (1964), Ellis (1971). Purification was carried out by reculturing the fungi by transferring single hyphal tip of each fungus on PDA media and incubated at $22 \pm 2^{\circ} \mathrm{C}$ for 7 days. The contaminated plates were discarded. 


\section{Bioassay of isolated fungi by using Dual culture method}

Three pathogenic fungi Fusarium oxysporum (the causal agent of dry rot of potato), Sclerotium rolfsii (the causal agent of foot and root rot of betel vine), Colletotrichum corchori (the causal agent of anthracnose of jute) were collected from MS Laboratory Department of Plant Pathology of Sher-e-Bangla Agricultural University, Dhaka. The fungi were cultured in PDA medium. The culture discs cut separately with the help of sterilized cork borer of isolates and pathogen was aseptically transferred and placed at periphery of the petri dish containing the PDA medium. Inoculated with culture discs of the pathogens alone in the petri dish containing PDA served as control. The inoculated petri dishes were transferred into the incubator and incubated at $25^{\circ} \mathrm{C}$. The growth of the fungus was observed periodically in petri-plates and measured the mycelial growth (diameter) in each petridishs were taken (Parvin et al., 2016).

After seven days of inoculation (7DAI), radial mycelial growth $(\mathrm{mm})$ of fungus was recorded. The radial mycelial growth $(\mathrm{mm})$ of each fungi (pathogen and antagonist) was measured by taking average of the three diameters taken for each colony (Parvin et al., 2016). Percent inhibition zone was estimated by the following formula as suggested by Johnson and Sekhar (2012).

Percentage inhibition of growth $=\frac{\text { C-T }}{\text { C }}$

$\mathrm{C}=$ Growth of fungus in control

$\mathrm{T}=$ Growth of fungus in treatment

\section{Statistical analysis of data}

Data collected during experiment period were tabulated and analyzed following Statistical package MSTAT-C. Treatment means were compared with Duncan's Multiple Range Test (DMRT)

\section{RESULTS AND DISCUSSION}

\section{Morphological characteristics of fungal isolates}

Aspergillus flavus grew rapidly producing colonies yellow green to green color with white mycelia at the edges (Fig. 1a). The conidia were finely rough, conidia heads were radiate to columnar with loosely packed phialides; the unisertiate conidia heads had radiate vesicle with the philiades covering upto three quarter of the vesicle; while bisertiate the vesicles were spherical to globose (Fig.1b).

Aspergillus niger was fast growing producing black conidial head at the center and white mycelia towards the edge which changed color to brown with age (Fig. 2a). The colonies had thick mat of floccose mycelia beneath the colonies and at the edges. It formed radial furrows very close to each other. Conidia heads were biseriate and 
globose in shape with wide spherical to globose vesicle. The stipe was large and wide with smooth and slightly brown color. Conidiophores were smooth walled, hyaline or turning dark towards the vesicle. Conidia was globose to subglobose in shape (Fig 2b). Similar structure was observed by Nyongesa et al., 2015, Wang et al., 1990 and Thilagam et al. 2016.

Trichoderma harzianum produced whitish to greenish colored mycelia in the beginning. Later a deep green color developed in central part and gradually extended to the periphery. Finally, it appeared a whitish green color (Fig. 3a). Mostly globose to subglobose conidia developed on phialides produced in the opposite direction in each point which observed under compound microscope. Conidiophores were septate, hyaline and loosely branched. Main branches produced lateral side branches. All primary and secondary branches arise at $90^{\circ}$ angles with respect to the main axis (Fig 3b). Similar features were found by Jahan et al. 2013, Samuels et al. 2002 and Shah et al. 2012.

The mycelial mass of Penicillium sp initially appeared white and then gradually turned green with sterile white margin (Fig. 4a). The texture was powdery, mycelia was radially furrowed with heavy sporulation. Hyphae was hyaline and septate. Conidiophores were erect, septate, and branched. Phialides were grouped in brushlike clusters (penicilli) at the ends of the conidiophores (Fig. 4b). Conidia was in long dry chains, round to ovoid, hyaline or greenish, smooth or rough-walled. (Larone, 1995).

\section{Biological efficacy of isolated fungi against three pathogenic fungi}

Trichoderma harzianum showed the best performance by reducing the growth of Sclerotium rolfsii in duel culture. The inhibition was $61.80 \%$, which was the highest inhibition percentage. Aspergillus flavus, Aspergillus niger and Penicillium sp. showed inhibition $57.60 \%, 45.78 \%$ and $19.27 \%$, respectively. The present findings agreed with the findings of Bosah et al., (2010). They conducted an experiment on the pure cultures of three antagonistic fungi, Trichoderma, Penicillium and Aspergillus species against Sclerotium sp. Among the three fungal antagonists evaluated for inhibitory efficacy, Trichoderma sp. proved to be the most effective as it exhibited the greatest inhibition to Sclerotium sp. both at the initial and final tests. This was closely followed by Aspergillus sp. with inhibitory effect on the pathogen at. However, Penicillium sp. was slightly inhibitory against Sclerotium (Table 1, Fig $5)$.

In in-vitro screening, Trichoderma harzianum showed best performance by reducing the growth of Fusarium oxysporum up to $71.75 \%$, which is the highest inhibition. The lowest result was found in Penicillium spp. (28.81\%). Aspergillus niger and Aspergillus flavus showed $49.07 \%$ and $33.10 \%$, respectively. The present findings is 
partially supported by findings of Kashem et al., (2011). They conducted a series of experiments to assess the effect of 14 isolates of Trichoderma spp. (Trichoderma harzianum and $T$. viride) for controlling foot and root rot of lentil caused by Fusarium oxysporum. The pathogenecity of 12 isolates of $F$. oxysporum and the mass production of an isolate of $T$. harzianum on 25 substrates are also studied. Trichoderma isolates inhibited the growth of $F$. oxysporum up to $92.07 \%$ on agar plates (Table 1, Fig 6).

Mycelial growth of Colletotrichum corchori in dual culture method was mostly affected by Trichoderma harzianum (57.24\%) followed by Aspergillus niger (47.95\%), Aspergillus flavus (42.37\%) and Penicillium sp. (39.96\%). The present findings is partially supported by Fitsum et al., 2014. They conducted an experiment on bean anthracnose caused by Colletotrichum lindemuthianum (Sacc. \& Magnus) Briosi \& Cavara is one of the most devastating seed-borne diseases of common bean (Phaseolus vulgaris L.) in Ethiopia. Three fungicides viz., Mancozeb, Folpan and Mancolaxyl, and three bioagents viz., Trichoderma harzianum Rifai, Trichoderma viride Pers. Fr. and Pseudomonas fluorescens Migula, were screened in vitro for their antifungal activities against common bean anthracnose, using the dual culture and microliter double-dilution techniques. The highest percentage of inhibition of the mycelia germination (80.39\%) was obtained from T. viride, followed by $75.49 \%$ from T. harzianum and $40.2 \%$ from $P$. fluorescens (Table 1, Fig 7).

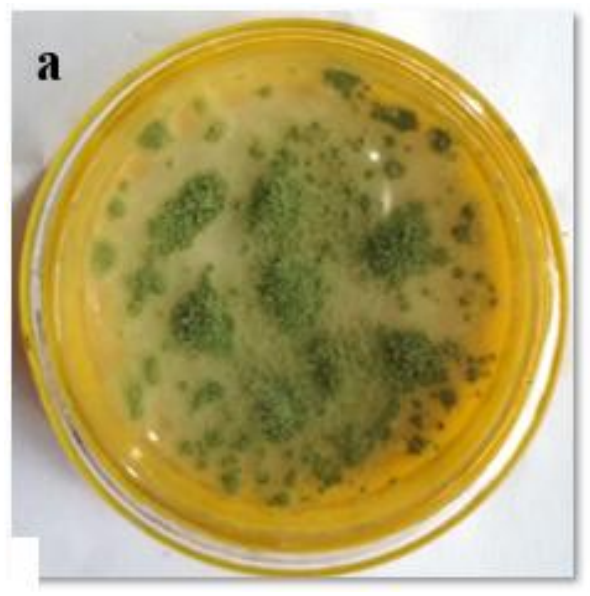

Figure 1. a. Aspergillus flavus on PDA medium b. Microscopic appearance of $A$. flavus at $40 \mathrm{X}$

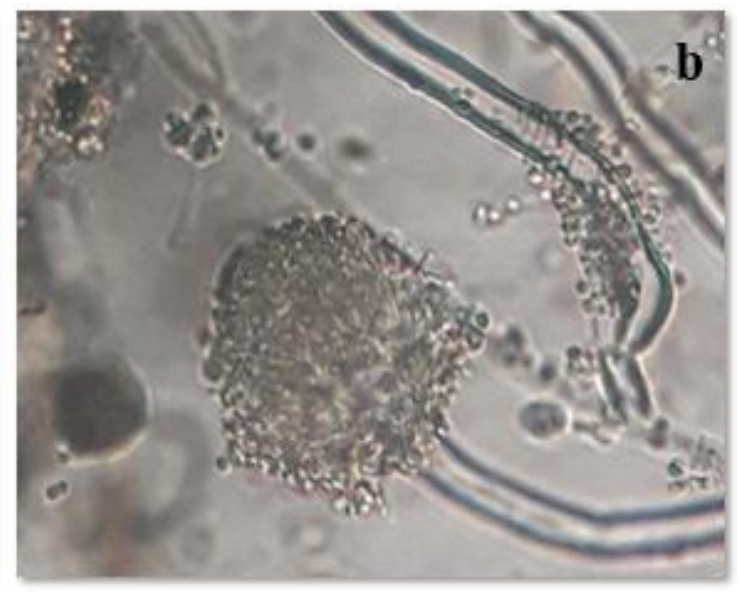



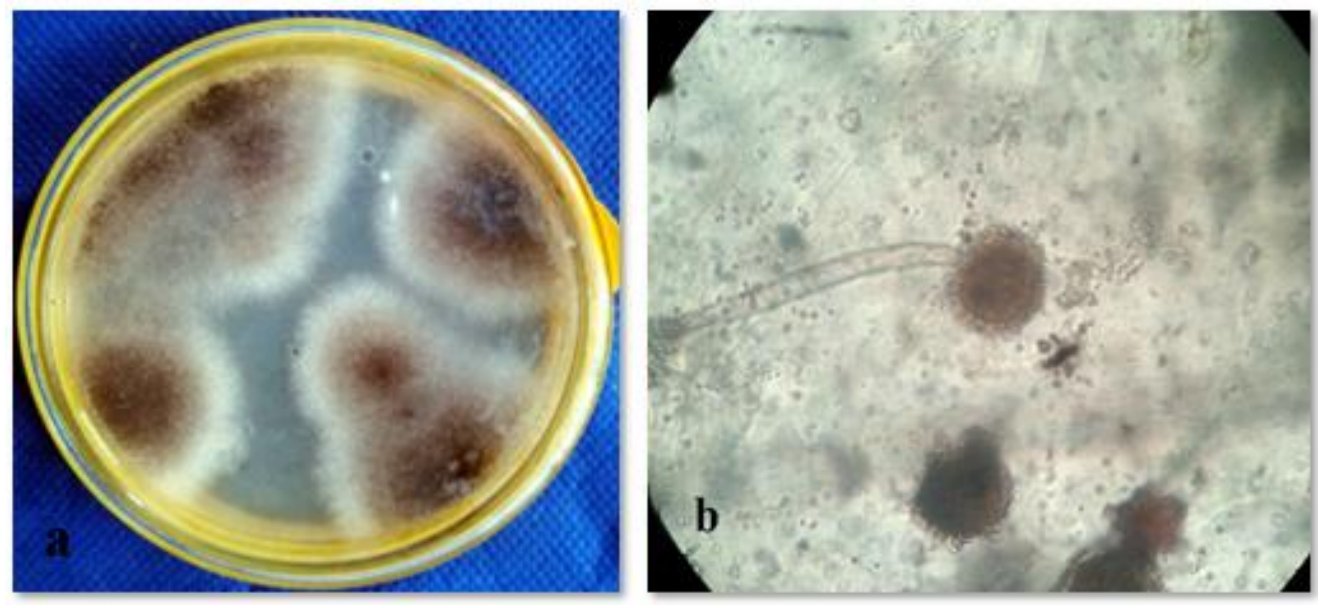

Figure 2. a. Aspergillus niger on PDA medium b. Microscopic appearance of $A$. niger at $40 \mathrm{X}$
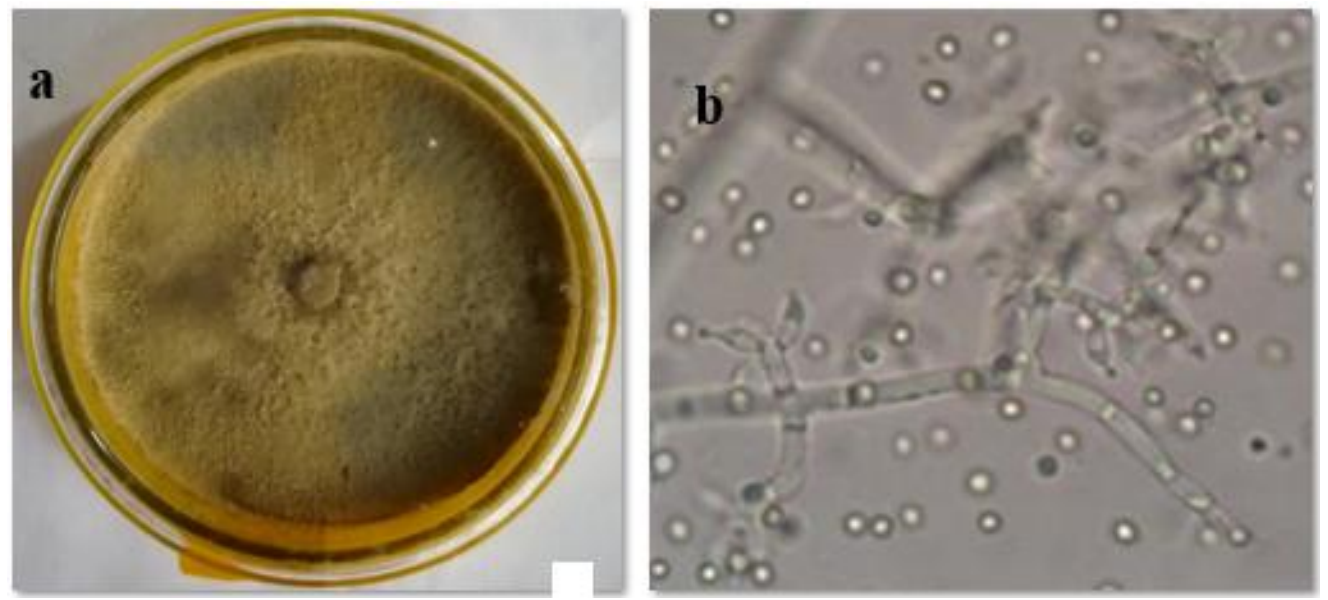

Figure 3. a. Trichoderma harzianum on PDA medium b. Microscopic appearance of T. harzianum at $40 \mathrm{X}$ 

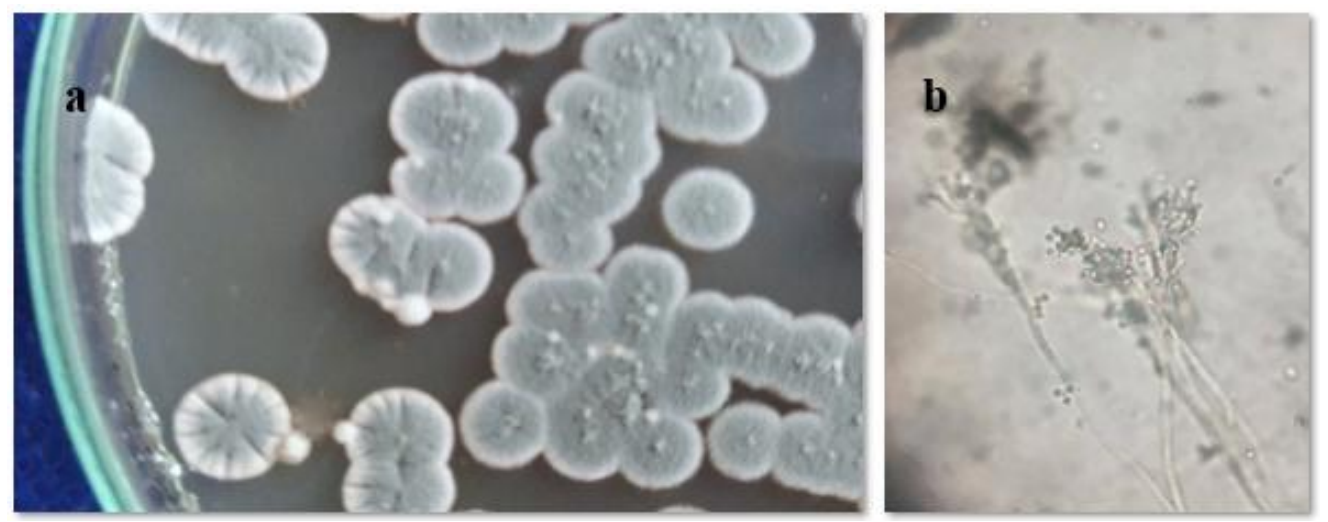

Figure 4. a. Penicillium sp on PDA medium, b. Microscopic appearance of Penicillium sp at $40 \mathrm{X}$

Table1. Biological efficacy of fungi isolated from mushroom substrate against Sclerotium rolfsii, Fusarium oxysporum and Colletotrichum corchori

\begin{tabular}{|c|c|c|c|c|c|c|}
\hline \multirow[t]{2}{*}{ Treatment } & \multicolumn{3}{|c|}{$\begin{array}{l}\text { Radial mycelial } \\
\text { growth }(\mathrm{mm}) \text { at } 7 \mathrm{DAI}^{*}\end{array}$} & \multicolumn{3}{|c|}{$\begin{array}{l}\% \text { Inhibition of mycelial } \\
\text { growth at } 7 \mathrm{DAI}^{*}\end{array}$} \\
\hline & $\begin{array}{l}\text { Sclerotium } \\
\quad \text { rolfsii }\end{array}$ & $\begin{array}{l}\text { Fusarium } \\
\text { oxysporum }\end{array}$ & $\begin{array}{l}\text { Colletotrichum } \\
\text { corchori }\end{array}$ & $\begin{array}{l}\text { Sclerotium } \\
\text { rolfsii }\end{array}$ & $\begin{array}{l}\text { Fusarium } \\
\text { oxysporum }\end{array}$ & $\begin{array}{c}\text { Colletotrichum } \\
\text { corchori }\end{array}$ \\
\hline $\begin{array}{l}\text { Penicillium } \\
\text { sp. }\end{array}$ & 67.00 & 30.75 & 32.30 & 19.27 & 28.81 & 39.96 \\
\hline $\begin{array}{l}\text { Aspergillus } \\
\text { flavus }\end{array}$ & 35.19 & 28.90 & 28.00 & 57.60 & 33.10 & 47.95 \\
\hline $\begin{array}{l}\text { Aspergillus } \\
\text { niger }\end{array}$ & 45.00 & 22.00 & 31.00 & 45.78 & 49.07 & 42.37 \\
\hline $\begin{array}{l}\text { Trichoderma } \\
\text { harzianum }\end{array}$ & 31.70 & 12.20 & 23.00 & 61.80 & 71.75 & 57.24 \\
\hline Control & 83.00 & 43.2 & 53.8 & - & - & - \\
\hline
\end{tabular}

*In column, DAI = Days after inoculation 

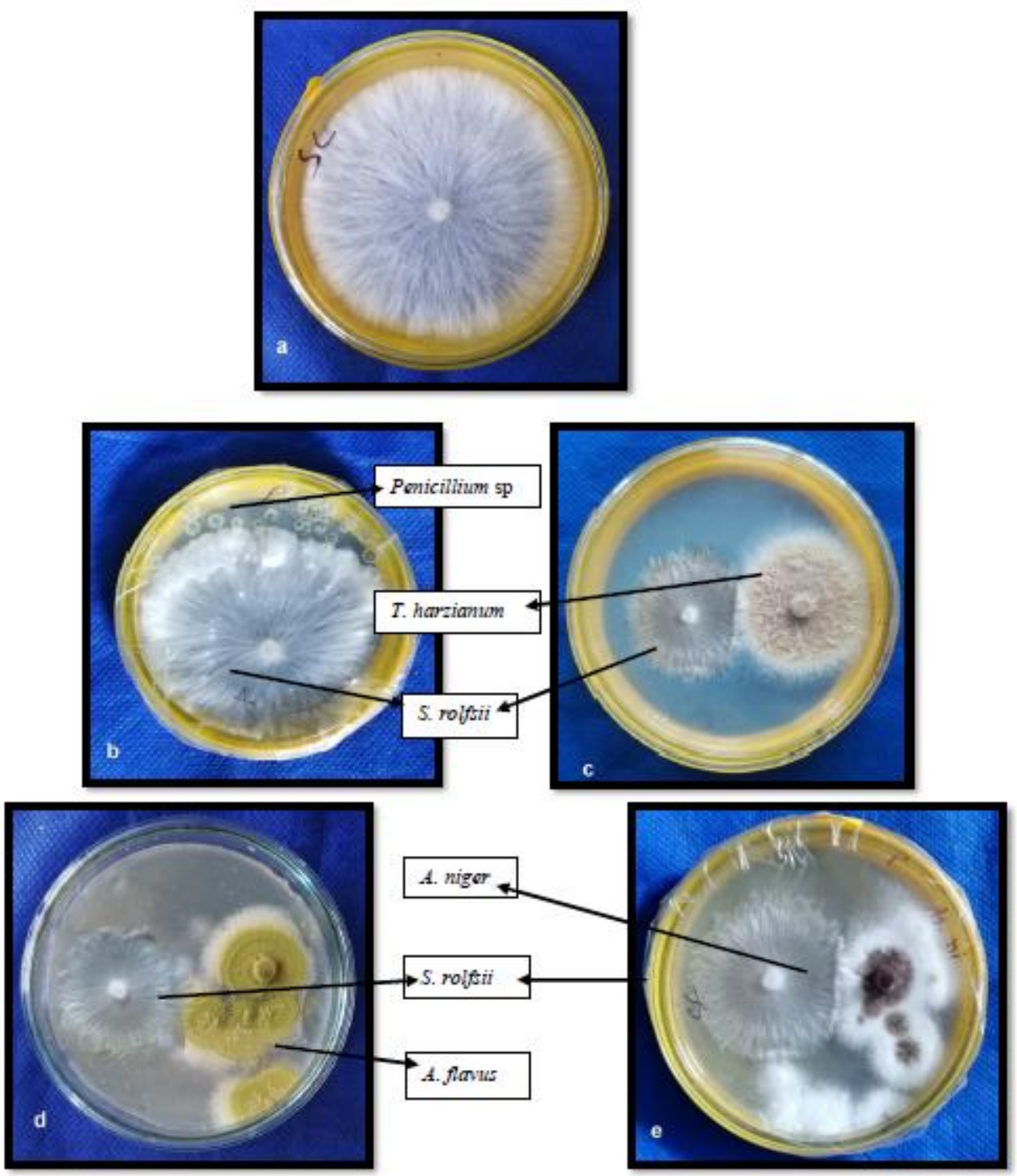

Figure 5. a. Growth of $S$. rolfsii at 7DAI b. Growth of $S$. rolfsii against Penicillium sp. at 7DAI c. Growth of $S$. rolfsii against $T$. harzianum at 7DAI d. Growth of $S$. rolfsii against $A$. flavus at 7DA e. Growth of $S$. rolfsii against A. niger at 7DAI 

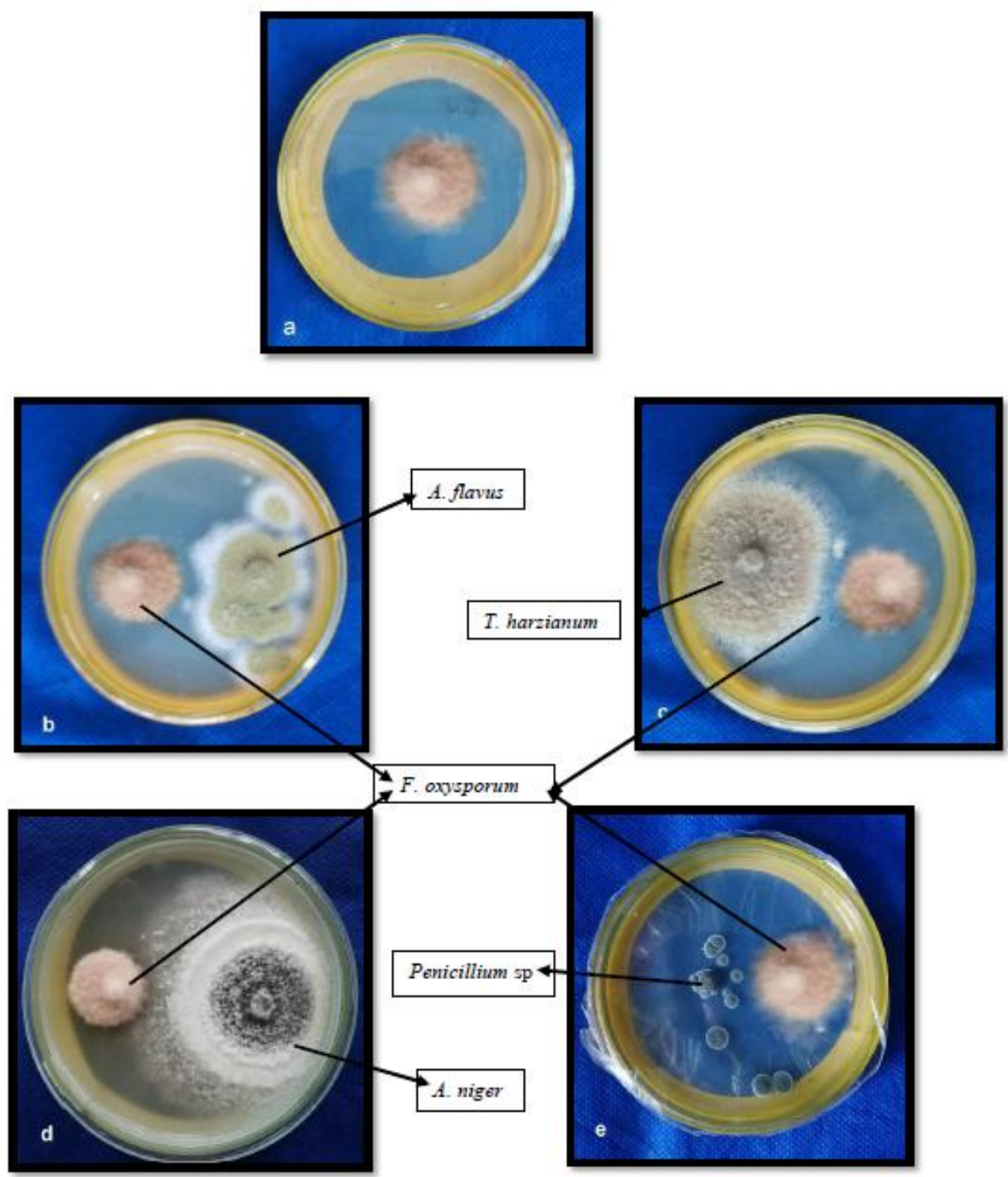

Figure 6. a. Growth of Fusarium oxysporum at 7DAI b. Growth of F. oxysporum against Aspergillus flavus at 7DAI c. Growth of $F$. oxysporum against $T$. harzianum at 7DAI d. Growth of $F$. oxysporum against Aspergillus niger at 7DAI e. Growth of $F$. oxysporum against Penicillium sp. at 7DAI 

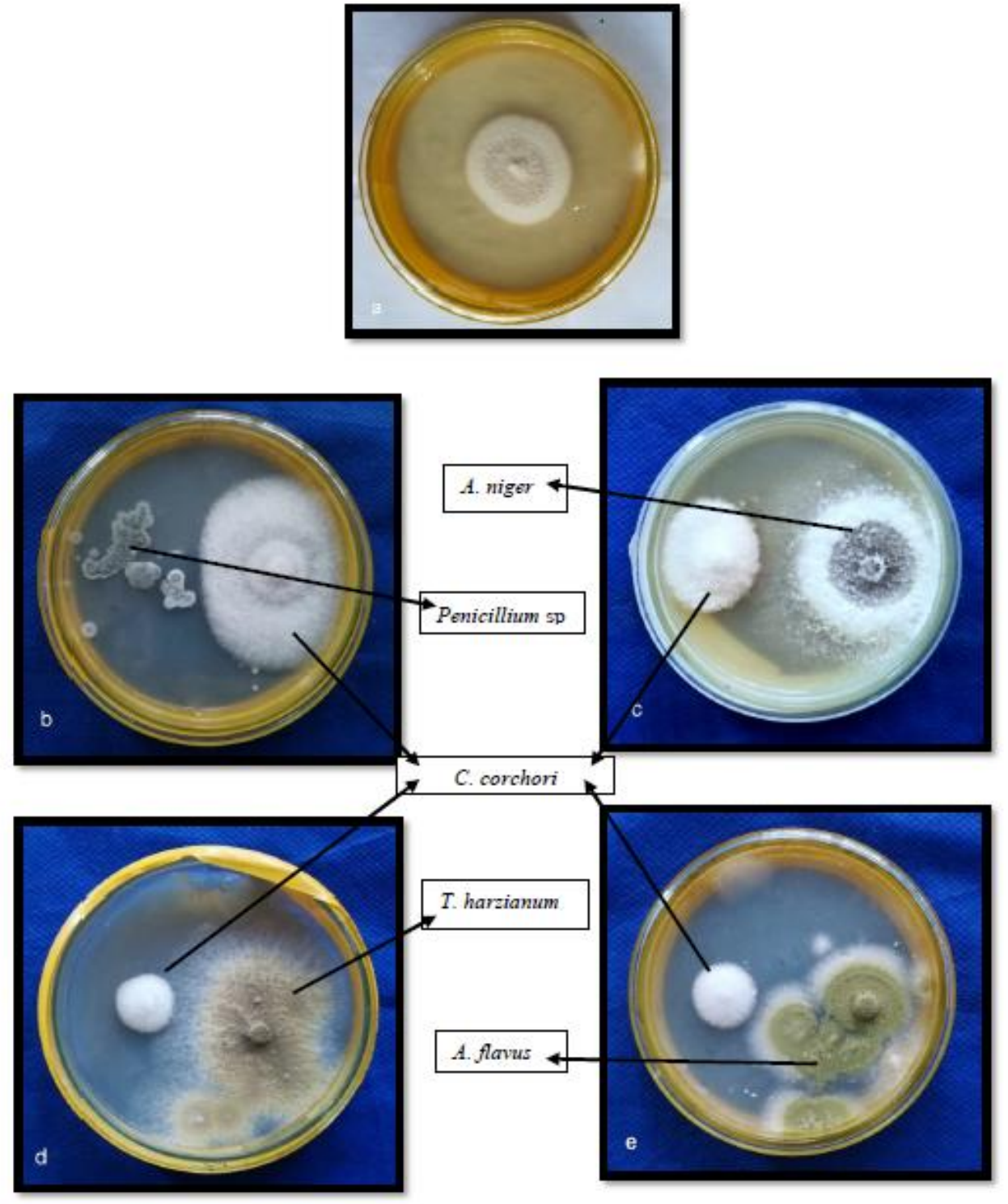

Figure 7. a. Growth of Colletotrichum corchori at 7DAI b. Growth of C. corchori against Penicillium sp. at 7DAI c. Growth of $C$. corchori against Aspergillus niger at 7DAI d. Growth of $C$. corchori against $T$. harzianum at 7DAI e. Growth of $C$. corchori against Aspergillus flavus at 7DAI 


\section{CONCLUSION}

Biological efficacy of fungal isolated from mushroom substrates against three pathogenic fungi were studied and found significant variation in terms of percent inhibition of radial mycelial growth of pathogenic fungi. In case of Fusarium oxysporum the highest inhibition was observed against $T$. harzianum $(71.75 \%)$ and the lowest against Penicillium sp (28.58\%). In case of Sclerotium rolfsii highest inhibition observed against T. harzianum (61.64\%) and the lowest against Penicillium sp (19.55\%). In case of Colletotrichum corchori highest inhibition observed against T. harzianum (57\%) and the lowest against Penicillium sp (39.59\%). It has been observed that among the fungal antagonist used against pathogenic fungi the most effective was T. harzianum.

\section{REFERENCES}

Barnet, H.L. (1980). In: Compendium of Soil Fungi. Burees Pub. Co. Minneapolis, U.S.A. p.223.

Barnett, H.L. and Hunter, B.B. (1992). In: Illustrated Genera of Imperfect Fungi Minneapolis: Burgess publishing Co. p.241.

Bosah, O., Igeleke, C.A. and Omorusi, V.I. (2010). In vitro microbial control of pathogenic Sclerotium rolfsii. International Journal Agricultural Biology, 12: 474-476.

Dhingra, D.D. and Sinclair, J.B. (1985). In: Basic plant pathology methods CRC Press Inc. Boca, Florida. p. 355

Ellis, M.B. (1971). In: Dematiaceous Hyphomycetes, Commonwealth Mycological Institute, Kew, Surrey England. p. 608. ISBN 85198-027-9.

Fitsum, S., Amin, M., Selvaraj, T. and Alemayehu, A. (2014). In vitro evaluation of some fungicides and bioagents against common bean anthracnose (Colletotrichum lindemuthianum Sacc. \& Magnus) Briosi \& Cavara. African Journal of Microbiological Research, 8(20): pp. 2000-2005

Goszczynska, T. and Serfontein, J.J. (1998). Milk-Tween agar, a semiselective medium for isolation and differentiation of Pseudomonas syringae pv. syringae, Pseudomonas syringae pv. phaseolicola and Xanthomonas axonopodis pv. phaseoli. Journal of Microbiological Methods, 32(1): 65-72.

Jahan, N., Sultana, S., Adhikary, S.K., Rahman, S. and Yasmin, S. (2013). Eavaluation of the growth performance of Trichoderma harzianaum (Rifai.) on different culture media. Journal of Agricultural Veterinary Science, 3: 44-50.

Johnson, M. and Sekhar, C.V. (2012). Principles of Plant Pathology: Practical manual. p. 67.

Kashem, M.A., Hossain, I. and Hasna, M.K. (2011). Use of Trichoderma in biological control of foot and root rot of lentil (Lens culinaris Medik). International Journal of Sustainable Crop Production, 6(1): 29-35.

Kwon, H. and Kim, S.B. (2004). In: Mushroom grower's Handbook. 1: Bag cultivation. Oyster mushroom Cultivation, pp. 160-173.

Larone, D.H. (1995). Medically important fungi: a guide to identification (No. Ed. 2). American Society for Microbiology. 
Malone, G.P. and Musket, A.E. (1964). Seed-borne fungi. Description of 77 fungus species. Proceedings of the International Seed Testing Association, 29(2):180-183.

Mathur, S.B. and Kongsdal, O. (2003). Common Laboratory Seed Health Testing Method for Detecting Fungi. First edition. International Seed Testing Association, Bassersdorf, Switzerland. p. 425.

Mian, I.H. (1995). Methods in Plant Pathology. IPSA-JICA Project Publication, No.24. pp.100.

Nyongesa, B.W., Okoth, S. and Ayugi, V. (2015). Identification Key for Aspergillus Species Isolated from Maize and Soil of Nandi County, Kenya. Advances in Microbiology, 5(4): 205.

Parvin, R., Aminuzzaman, F.M., Islam, M.S., Hasan, N., Begum, K. and Roni, M.Z.K. (2016). In vitro efficacy of some fungicides, plant extracts and bio-agents against sclerotium rolfsii and control of foot and root rot disease of betel vine. International Journal of Business Social and Scientific Research, 4(3): 211-220.

Ragunathan, R., Gurusamy, R., Palaniswamy, M. and Swaminathan, K. (1996). Cultivation of Pleurotus spp. on various agro-residues. Food Chemistry, 55(2): 139-144.

Samuels, G.J., Dodd, S.L., Gams, W., Castlebury, L.A. and Petrini, O. (2002). Trichoderma species associated with the green mold epidemic of commercially grown Agaricus bisporus. Mycologia, 94(1): 146-170.

Sanchez, C. (2010). Cultivation of Pleurotus ostreatus and other edible mushrooms. Applied microbiology and biotechnology, 85:1321-1337.

Shah, S., Nasreen, S. and Sheikh, P.A. (2012). Cultural and Morphological Characterization of Trichoderma spp. Associated with Green Mold Disease of Pleurotus spp. in Kashmir. Research Journal of Microbiology, 7(2): 139.

Sharma, S.R., Kumar, S. and Sharma, V.P. (2007). Diseases and Competitor Moulds of Mushrooms and their Management. Technical Bulletin. National Research Centre for Mushroom. Chambaghat, Solan, India. pp. 1-43.

Sharma, V.P. and Kumar, S. (2011). Competitor moulds and diseases in mushroom production and their management. Mushrooms cultivation, marketing and consumption. Directorate of Mushroom Research (ICAR), Chambaghat, India. pp. 155-174.

Thilagam, R., Hemalatha, N., Poongothai, E. and kalaivani, G. (2016). Identification of aspergillus species isolated from corn and peanuts in storage godowns. International Journal Biological Science, 7(4): 600- 606

Tuite, J. (1969). In: Plant Pathological Methods. Fungi and Bacteria Burgess Pub. Co. Minneapolis, Minn. USA. p. 293.

Vijay, B. and Sohi, H.S. (1987). Cultivation of oyster mushroom Pleurotus sajor-caju (Fr.) Singer on chemically sterilized wheat straw. Mushroom Journal of Tropics, 7: 67-75.

Wang, C.J.K. and Zabel, R.A. (1990). Identification manual for fungi from utility poles in the eastern United States. American Type Culture Collection. Phytopathology, 61(3): 432-437.

Watanabe, T. (2000). In: Pictorial Atlas of Soil and Seed Fungi: Morphologies of Culture Fungi and key to Species. CRP Press LLC. p.506.

Wickremasinghe, R., Abeywickrama, K.P. and Abeythunga, D.T.U. (1999). Isolation and identification of fungi from mushroom composts and evaluation their biological activity. Journal of the National Science Foundation of Sri Lanka, 27(1): 29-40. 